\title{
The Economic Transformation of the Inca Heartland (Cuzco, Peru) in the Late Sixteenth Century
}

\author{
R. ALAN COVEY \\ Department of Anthropology, University of Texas at Austin
}

\author{
KYLIE E. QUAVE \\ Department of Anthropology, Beloit College
}

In a single lifetime following the European invasion of the Andes in the 1530s, the region surrounding the Inca capital of Cuzco experienced profound economic transformations. The first Spanish eyewitnesses described the Inca heartland as a densely-settled region with a socially and ethnically diverse population that lived in farming and herding villages or served on country estates belonging to noble Inca families (e.g., Sancho de la Hoz 1962 [1534], ch. 17). Llama caravans transported provincial surpluses of maize, potatoes, and other crops to Cuzco or to local Inca storage facilities, and raw materials for producing fine craft goods flowed to the capital region. Inca rulers and their offspring used maize from productive valley-bottom terraces and coca leaf from plots on the nearby Amazonian slope to fuel festive events in Cuzco that reciprocated the service of local and provincial subjects. Inca nobles and the state religion did not monopolize the means of production in rural Cuzco, but they exercised variable degrees of control over a diverse

Acknowledgments: The first author conducted research at the Archivo General de la Nación (Lima) in 2000 while supported by a Fulbright-Hays DDRA Fellowship. A National Science Foundation grant (BCS-0342381) supported additional work in that archive in 2004, as well as work by Donato Amado Gonzáles in the Archivo Regional del Cuzco and other local archives from 2004-2006. Additional work in these archives was funded by a National Endowment for the Humanities Collaborative Research Grant to the first author (RZ-50818-07) from 2007-2009. The American Museum of Natural History and Southern Methodist University funded research by the first author at the Archivo General de Indias (Seville) in 2004, 2006, and 2010. The material support for this project is gratefully acknowledged, as is the assistance of archival staff and local authorities. We offer particular thanks to Donato Amado Gonzáles for his help in acquiring key documents used in the present study, and thank the anonymous CSSH reviewers who commented on an earlier draft of this manuscript. 
array of productive environments and the labor of tributary and retainer populations.

From this view, Cuzco's rural economy was almost unrecognizable by the end of the sixteenth century. Although artifacts of the great estates of the 1530s remained and the idiom of Inca tributary practices persisted-in yanacona retainers, and rotational mita labor drawn from tributary populations-the former Inca heartland had been utterly overturned. Migration, war, and disease had transformed the region's ethnic constituency, altering the balance between local subsistence requirements and labor available for production of surplus. The Columbian exchange introduced new crops and herd animals, which became commodities alongside Andean maize and coca (Gade 1992). Surpluses flowed not to Cuzco, but to the booming mining center at Potosísix hundred thousand head of European livestock in 1597, 680 metric tons of coca leaf in 1610, and unknown quantities of wheat and maize (Robins 2011: 42; Stern 1995: 73). Haciendas were proliferating in a climate of conflict with indigenous communities, as the growing Spanish republic expropriated indigenous community lands and imposed unsustainable labor demands.

The colonization of rural Cuzco unfolded over decades, punctuated by civil unrest and deadly epidemics that decimated the indigenous population and altered the composition of Europeans living in the region. As waves of Spaniards migrated to the former Inca heartland, they promoted their individual interests through Iberian municipal practices, while also exploiting native peoples using evolving colonial institutions. It took decades for royal officials to wrestle control from the original conquerors and to develop institutions for the long-term administration of "Indians" and "Spaniards" (e.g., Assadourian 1994; Varón Gabai 1997). Many scholars view the tenure of the viceroy Francisco de Toledo (1569-1581) as the first realization of Spanish colonial rule in the Andes, through the promulgation of new policies that resettled indigenous populations into ordered, European-style towns and established new policies on taxation and legal administration (e.g., Mumford 2012).

Despite the ambitions of the Toledan administrative program, early seventeenth-century writers already viewed them as a failure (e.g., Mumford 2012: 143-56; Wightman 1990: 15-25). To illustrate how they fell short of expectations, we will look a generation later, focusing on documents from the 1594-1595 visita y composición de tierras, an administrative visit that allocated community land to indigenous individuals and confirmed private property titles. We use detailed records from the composiciones de tierras in four colonial towns to the west of Cuzco (figure 1) to address long-term outcomes of Toledo's resettlement programs and tribute levies. The 1590s documents signal the inability of Toledan policies to create subject communities of Christianized Indians and expose how the erosion of indigenous control over the means of production instead transformed the indigenous population of the former imperial heartland into peasants. 


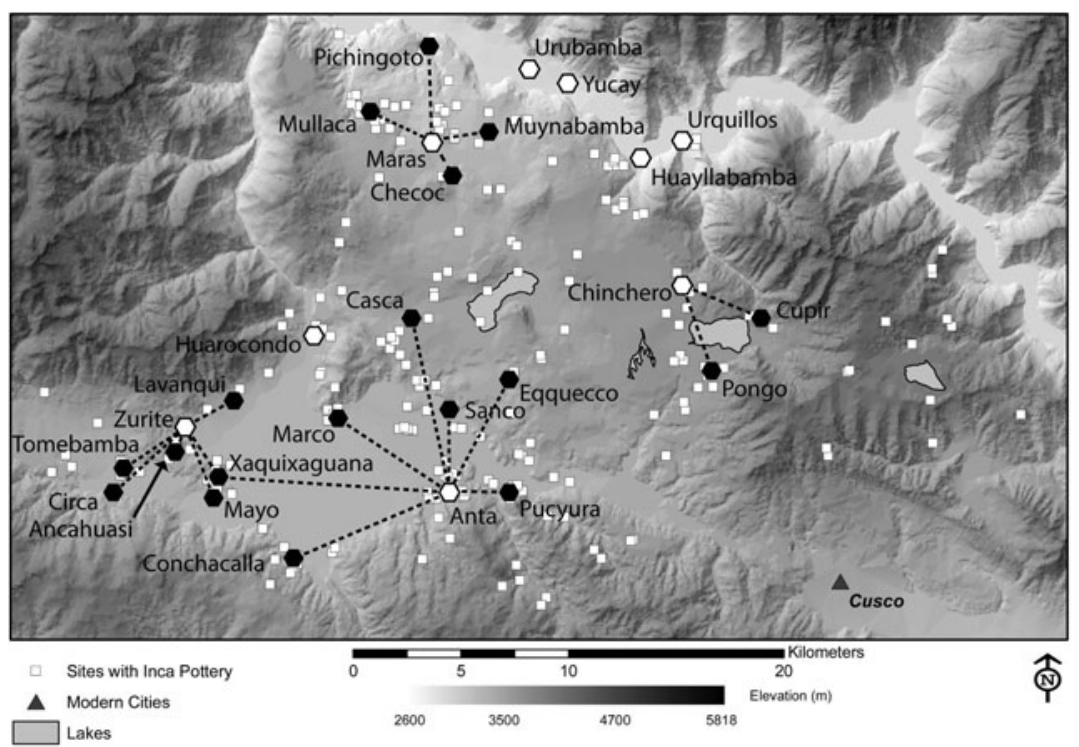

Figure 1. Map of the study region, showing Inca archaeological sites (small boxes), colonial reducción towns (white hexagons), and, where known, Inca-era communities reduced into those towns (black hexagons).

\section{THE ADVENT OF ROYAL POWER IN RURAL CUZCO}

For decades following the Pizarro expedition, royal officials were more or less absent in the Andean countryside. The encomienda system functioned with limited royal oversight in the early years, and attempts to curtail conquistador privileges provoked repeated rebellions during the 1540s and $1550 \mathrm{~s} .{ }^{1}$ Royalist victories presented delicate opportunities for administrative consolidation. Crown officials rewarded loyalists with properties confiscated from defeated rebels, but subsequent attempts to inhibit the most egregious encomienda practices inspired further violent resistance. Royal authority in Spanish Peru grew conservatively, preserving as much of the existing order as was necessary to

${ }^{1}$ Encomienda grants made Spaniards the trustees of indigenous populations. In principle, Spaniards provided religious instruction in return for labor and material support. By the second half of the sixteenth century, the Spanish Crown curtailed the institution to fixed-term grants (usually two generations), often of a specified sum from the total revenues generated by a particular population. In late sixteenth-century Cuzco, these are frequently referred to as repartimientos, although the term can be applied to other classes of forced indigenous labor. Francisco de Toledo attempted to guarantee Spanish access to indigenous labor through the mita, an adaptation of Inca rotational labor practices whereby indigenous groups made a proportion of their population available for wage labor in mining, agriculture, textile mills, and other Spanish enterprises. 
guarantee cooperation from most Europeans and Andean elites. Although royal officials began to collect population counts, identify tribute requirements (tasa), and conduct limited resettlement programs (reducción) among some Andean populations (e.g., Hampe 1979 [1561]; Rostworowski 1983-1984; Villanueva 1970 [1558]), such activities did not constitute a clearly articulated administrative strategy, and the scant known documentation suggests that they had limited impact before 1570 (e.g., Mumford 2012). ${ }^{2}$ Early on, the Crown attempted to approximate Inca precedents, and the administrative efforts depended heavily on the participation of Andean administrators or record-keepers. ${ }^{3}$ The reliance by royal officials on Andean elites and an Inca status quo ante was consistent with legal proceedings at the level of the cabildo and audiencia. ${ }^{4}$ In Cuzco, Inca claims retained particular authority (e.g., Rostworowski 1962).

After years of weighing the justifications for royal administration and the methods that consolidation should pursue, Philip II sent his viceroy Francisco de Toledo to Peru in 1568 with a mandate to implement reforms that would increase royal authority, raise revenue, and facilitate missionary work among indigenous populations (see Merluzzi 2014). Toledo became convinced that native settlement practices were an impediment to this mission:

I came to have evidence that in no way could the Indians be catechized, indoctrinated, and taught, nor could they live in civil or Christian order so long as they should be living where they were, in the punas [high grasslands], gullies and canyons, and on the hills

\footnotetext{
2 The Spanish reducción derives from the Latin reducere, "to lead back, accompany," and its use reflects changing political, religious, and administrative attitudes toward "Indians" from the early period of colonization in the Caribbean to the Toledan reforms (Hanks 2010: 2, 187; see Mumford 2012: 1, 44-49). The connotation of reducción - to reassemble a wayward and scattered flock - should be considered in the broader context of the Counter-Reformation, and the language of resettlement in other times and places, such as the congregaciones in Guatemala, which use a similarly biblical herding metaphor (e.g., Lovell and Swezey 1990). Both of these terms relate to policia (urban and civil order, from the Latin politia), a civilization concept that eventually materialized as a gridded town with all of the requisite municipal and religious infrastructures. A 1575 letter from the viceroy Toledo (1899 [1575]: 32) reveals the intended cause and effect between resettlement, reform of indigenous minds and habits, and the establishment of a Catholic law and order: "... the natives should be reduced and congregated in towns where they can be instructed and occupied in good civil order, natural law, and evangelical doctrine" (los naturales se reduzgan é congreguen á pueblos donde pueden ser enseñados é industriados en buena policía, ley natural é dotrina evangélica).

3 A 1549 visita in Huánuco consulted Paucar Guaman, a kuraka of four thousand Inca-era households (Helmer 1955-1956), and the inspector questioned local caciques about Inca-era tribute requirements. The 1558 reducción of the Yucay Valley solicited khipu and oral accounts of the local population through cacique testimony (Villanueva 1970: 56). Around 1564, Polo de Ondegardo (1917: 155) described using older Inca men to identify precolonial boundary markers in Cuzco. See Herzog (2013) on the consequences of legal recognition of indigenous practices.

4 The cabildo was the town council, first for the citizens of Spanish towns, although reducción communities were intended to adopt this form of local governance as well (see Mumford 2012: 146-48). Audiencias dealt in higher-order administrative matters, and a major focus of Toledo's new ordinances was relieving these bodies from troublesome local proceedings that could be moderated by lower-order royal officials.
} 
and mountains, where they were divided and hidden, having fled the treatment and communication of the Spaniards that was loathsome to them. And because in [those places] they continued to preserve the adoration of their idols and rites and ceremonies of their ancestors ... the priests and monks could not enter to indoctrinate them... (Toledo 1867a [1582]: 13, authors' translation).

Highland Andean populations would not become good Christians without radical alteration to local cultures and communities. Toledo targeted indigenous elites as a threat to the new civil and moral order: "The government that the Indians had was the same and hardly more ordered than they had in the time of the Inca tyranny ... the Curacas [Inca administrators] and Caciques principales [indigenous leaders] had them so subjected that nothing they commanded them would not be taken as law" (ibid.: 16, authors' translation). Toledo viewed indigenous elites as tyrants who actively impeded the spread of Christianity and the rule of law.

His solution was the visita general, a five-year undertaking whereby inspectors collected indigenous population counts, levied new tribute demands, and resettled and reduced the population into nucleated towns to facilitate administration and evangelization. ${ }^{5}$ Unlike earlier proceedings, Toledo ordered that local caciques cooperate with the visita, but inspectors often bypassed their local knowledge regarding Inca precedents and indigenous records. For example, in the Yucay Valley the 1558 reducción relied solely on cacique testimony (Villanueva 1970), but in the 1571 Toledan visita the inspector Pedro Gutiérrez Flores announced to the caciques that he would record settlement data based on his own observations (Covey and Amado González 2008). Gutiérrez Flores ultimately copied population information tabulated two years earlier by the local priest (Covey, Childs, and Kippen 2011).

Toledo intended to detach indigenous Andean populations from their sacred and productive landscapes and from existing social and political hierarchies, thereby transforming them into Christian Indians. Establishing new Indian towns and imposing explicit tribute requirements (tasas) would reduce the number and privileges of indigenous title-holders and also create municipal authorities whose duties and salaries were more clearly specified. The tasas would check the power of encomenderos by funding local judges

\footnotetext{
5 There is an extensive bibliography on the Toledan reducciones, and many documents from the viceroy's ordinances and correspondence have been published (e.g., Toledo 1921a; Levillier 1940; see Málaga Medina 1974). Recent scholarship has focused on the administrative aims of the Spanish Crown (Merluzzi 2014), the implementation of resettlement in the Andean highlands (Mumford 2012), the collision of Spanish and Andean visions of social order (Gose 2008; Scott 2009), and the effects on life in indigenous communities (Wernke 2013; Zuloaga Rada 2012). Saito and colleagues (2014) offer a review of recent literature, which largely addresses former Inca provinces. Although this literature is valuable, we focus here on administrative documents specific to the Cuzco region, as well as primary texts, to address some processes particular to the transformation of rural life in the Inca capital region.
} 
and defensores de indios and specifying the encomendero's net income. ${ }^{6}$ Enumerating the indigenous population was essential to establish a sustainable tribute system and determine the amount of indigenous wage labor available for Spanish projects in cities, mines, and country estates (Toledo 1867a: 21-22).

Toledo addressed Inca sovereignty and administrative practices while designing the new colonial order (see Mumford 2012: 112-16). He collected testimonies regarding Inca administration in local contexts, and retained some practices expected to generate state resources or reduce administrative costs. For example, Toledo ordered that caciques continue the "ancient Inca" custom of public feasts that would feed poor Indians (1867c: 210 [1574, Ordenanza XIX]). Nevertheless, the viceroy was explicit that Inca-era conditions would no longer serve as the basis for tribute levies, and by extension, access to productive resources. Noting that indigenous populations had changed since Inca times, Toledo ordered that land repartitions and turns of labor service conform to current population counts (ibid.: 214-16 [1574, Ordenanzas XXIX-XXX]), and that lands be distributed equally between the social groups comprising each repartimiento, "even though the Indians of those parcialidades [moieties] and ayllus [coresidential groups] from whom they would have to take lands for other ayllus and parcialidades should state and allege that they hold those lands and have possessed them since the time of the Inca" (ibid., authors' translation). ${ }^{7}$ Couched in terms of fairness and concern for native population growth, this command asserted a new legal basis for indigenous landholding and facilitated the reduction of the broader landscape claimed by Andean social groups from Inca times and earlier. Rather than control the region across which its constituent population lived and labored, an ayllu or parcialidad would receive lands appropriate to its subsistence needs and tasa requirements, designated with new boundary markers. Lands were to be equally distributed among individuals, and the corregidores would conduct new population counts every three years to determine whether tributary groups (and their land needs) had grown or shrunk (ibid.: 216).

The moral authority of the Toledan reducciones depended on successfully removing indigenous subjects from the alleged tyranny of their local ecology, customs, and social hierarchies and integrating them into well-ordered

\footnotetext{
6 The inclusion of tasa funds for municipal officials buttressed the recent creation of corregidores de indios, appointed by the king or viceroy. Toledo promoted local legal oversight to unburden the audiencias from what he saw as an overly litigious indigenous population (1867a: 19-21). Toledo noted (ibid.: 18) that designating priestly salaries in the tasa would also prevent the clergy from abusing their congregants.

7 The ayllu was an indigenous group that cooperated to manage land tenure and subsistence activities. It could be kin-based or simply co-residential, and the use of the term is muddled by the reducciones, since many settlements that were constituted as villages became ayllus in new colonial towns. In this study, we use the term to describe social groups that were settled in reducción towns, but which did not always belong to the same repartimientos as their municipal neighbors for the purposes of taxation or wage labor demands.
} 
Christian towns - an act of colonial ethnogenesis to establish them securely as subjects of the Spanish Crown. The fragmentary documentation of how the reducciones actually proceeded exposes the compromises (and corruption) underlying the implementation of royal claims over the Indian republic in the Peruvian Andes. Because the reducciones did not reconfigure repartimiento grants, Toledo's inspectors settled tributary populations inconsistently, often in multiethnic agglomerations that belonged to multiple repartimientos (Mumford 2012). In many cases reducciones were established in an existing community, and inspectors did not reallocate land among the new town's residents. Despite orders that individuals moving to new communities should be given good lands nearby (Toledo 1867c: 176-77 [1574, Ordenanza 37]), the original populations of many reducción towns retained the best local agricultural resources, and newcomers had to journey beyond those traditional holdings to their own ancestral fields and pastures.

Toledo acknowledged the ecological complexity of the Andean highlands and the need for land allocations and tribute levies to reflect local agrarian potential - of the repartimientos, rather than the new reducción towns. The tasas imposed annual demands of tribute in kind that were roughly tailored to local landscapes. To the west of Cuzco, the Toledan tasas specified three tribute crops - maize, wheat, and potatoes - to be paid in different proportions, with potatoes paid in their dried form (chuño) in one case (table 1). Although the tasas treated maize, wheat, and dried potatoes as commodities of equivalent market value, the land, water, and labor resources required for production varied by location. Groups already farming irrigated Inca maize terraces could cultivate their tribute in kind with little modification to existing local subsistence practices, whereas the production of wheat involved a riskier conversion of farmland or pastures, and new labor schedules. To generate tributary surpluses, the intensification of tuber cultivation might require alterations to crop rotations, fallow cycles, and reciprocal labor networks.

As Toledo sought to reorganize rural space into more legible subject towns with reduced subsistence resources, he also addressed Spanish Peru's need for labor. The new ordinances scrutinized existing labor relationships, promoting rural landscapes where tributary Indian communities would provide wage labor needed for Spanish projects. The viceroy prohibited people of African heritage from living in indigenous communities in rural Cuzco (1867b: 92 [1572, Título XXII]), and ordered that unauthorized retainers - those beyond what was "appropriate for ordinary service"-be removed from the houses and estates of encomenderos and property owners and placed in reducciones as tributaries (ibid.: 109 [1572, Título XXIX]). ${ }^{8}$ Noting that some Spaniards

\footnotetext{
${ }^{8}$ After the 1570 s, individuals of African descent still labored in rural Cuzco, and some were owners of herding stations. The persistence of so-called yanaconas suggests that the viceroy's orders did not eliminate retainer labor, either.
} 
TABLE 1.

Toledan Tasas from Repartimientos in the Xaquixaguana and Yucay Valleys of Rural Cuzco

\begin{tabular}{|c|c|c|c|c|c|c|c|c|c|c|c|}
\hline \multirow[b]{2}{*}{ Repartimiento } & \multirow[b]{2}{*}{ Trib. } & \multirow[b]{2}{*}{ Silver } & \multirow[b]{2}{*}{ Maize } & \multicolumn{2}{|c|}{ Income (Pesos) } & \multirow[b]{2}{*}{ Birds } & \multirow[b]{2}{*}{ Total } & \multicolumn{3}{|c|}{ Payments (Pesos) } & \multirow[b]{2}{*}{ Encom. } \\
\hline & & & & Wheat & Potato & & & Priest & Legal & Cac. & \\
\hline Yucay & 708 & 2816 & 675 & 0 & 0 & 29 & 3520 & 602 & 443 & 125 & 1646 \\
\hline Alpasondor & 26 & 100 & 12.5 & 9 & 0 & 1 & 125 & 48 & 16 & 6 & 52 \\
\hline Maras & 240 & 829 & 171 & 171 & 0 & 13.5 & 1185 & 188 & 150 & 60 & 331.5 \\
\hline Canco y sujetos & 615 & 2440 & 270 & 270 & 40 & 30 & 3050 & 610 & 383 & 120 & 1325 \\
\hline Puquiura & 231 & 916 & 85.5 & 85.5 & 25 & 33 & 1145 & 246 & 144 & 30 & 496 \\
\hline Pomaguanca y Ancaguaci & 348 & 1376 & 120 & 150 & 40 & 34 & 1720 & 348 & 217 & 70 & 741 \\
\hline Cupirpongo y sus sujetos & 264 & 1286 & 30 & 60 & 160 & 12 & 1179 & 204 & 165 & 80 & 468 \\
\hline
\end{tabular}

Notes: Data are taken without correction from Cook 1975. Tributaries (Trib.) are married men aged 18-50. For Cupirpongo, the "Potato" category includes 150 pesos of dried potatoes (chuño). Costs comprise doctrina (Priest), representation by justicias and defensores de indios (Legal), and incomes for caciques (Cac.). The encomendero (Encom.) received the remainder, less the one-fifth paid to the Crown. 
cheated Indians of their wages, Toledo ordered that indigenous laborers be paid annually in Cuzco, respecting a 1571 cabildo wage scale that designated daily and annual pay for different labor categories (ibid.: 109-11 [1572 Título XXIX]). Wage labor was to come primarily from tributary communities, but the designation of compensation and material support for minors and the elderly indicates that the viceroy intended for all indigenous people to be available to work for Spaniards in their houses, gardens, fields, and pastures. Toledo acknowledged that his new ordinances could make it harder for Spaniards to coerce indigenous laborers, so he ordered local officials to compel all unoccupied Indians to hire themselves to Spaniards. Tributary communities to the west of Cuzco were not subject to mining service at Potosí, but were ordered to perform rotational labor in Cuzco and to provide one-seventh of their heads of household for wage labor on neighboring Spanish estates, and more workers at harvest time.

COMPOSICIONES DE TIERRAS IN RURAL CUZCO

The implementation of Toledo's new ordinances fell far short of their rhetoric and detail. Study of the documents produced a generation later-specifically the composiciones de tierras of rural Cuzco - reveals the extent of the failure to create new Christian Indian towns operating in tandem with Spanish Peru. In 1591, Philip II issued a royal cédula ordering that his viceroy, García Hurtado de Mendoza, oversee the legal repartition of lands in Peru (Torres Saldamando 1879). This proceeding built on a 1589 cédula stating that only royal officials could grant titles to lands in the Americas, a declaration that negated earlier titles from municipal authorities and other officials (Amado Gonzáles 1998: 198). By claiming the exclusive power to grant land titles, the king established himself as the sole authority who could determine whether lands were vacant and whether claimants made a compelling case for ownership.

The viceroy appointed Alonso Maldonado de Torres, an oidor of Lima's royal audiencia, as presiding judge in Cuzco, and he in turn named inspectors (visitadores) to oversee the inspection of private properties and to visit reducción towns in 1594-1595 (ibid.: 198-99). For private lands, Maldonado de Torres issued an act "in which he ordered that all of those who have lands, coca plots, herding facilities, and other possessions in the vicinity of this city, and in the towns and valleys of the corregimientos of its district, should show the titles that they have in order to be able to possess them." ${ }^{\text {"9 }}$ Landowners seeking title presented petitions or testimony describing the size, location, and boundaries of their land, and information about its purchase. Once Maldonado de Torres confirmed the title, an inspector visited the plot and an official

\footnotetext{
9 AGI Escribanía 506A 1625 [1594] f. 45v: "en que mando que todos los q tienen tierras chacras de coca estançias y otras poseçiones en terminos desta çiudad y en los pueblos y ualles de los corregimientos de su distrito exsiuiesen los titulos que para las poder poseher tienen."
} 
measurer (medidor) delimited the lands and confirmed boundary markers (e.g., AGN, Derecho Indígena, L.13, C.302 [1594]).

For indigenous lands, inspectors received commissions to visit reducción towns, where they presented a second act from Maldonado de Torres, "in which he declared all the lands ... to belong to His Majesty and to his Royal Crown, that in effect they are such for being the king and natural lord of these Kingdoms. And in it, he told them and made them understand, that His Majesty, as king and so powerful and pious a lord, commanded that they be given and have distributed to them lands for their sustenance, to pay the tax and tribute that they owe, and for other things that were appropriate."10 The inspector then determined the location and size of lands pertaining to different ayllus and measured out lands deemed appropriate for their subsistence and tasa needs. After the distribution of land to individuals in the ayllu, the inspector identified "surplus" lands that the Crown could sell or grant to private individuals (e.g., AGN, Títulos de Propiedad, L.2, C.40 [1595]). Following the auction of surplus lands, administrators frequently returned some portion of unsold lands to the indigenous group that had formerly possessed them, so that "extra" lands remained in the royal domain where they could be alienated from indigenous subjects in future proceedings.

The composiciones de tierras emphasized two aspects of Spanish sovereignty. In the "republic of Spaniards," confirmation of titles reinforced the royal claim to have the exclusive authority to expropriate resources from the Indian domain, to make them available to "Spanish" subjects. By the 1590s, royal officials confronted a complicated tangle of land transfers and transactions set in motion by decades of municipal land allocation and local sales and swaps. ${ }^{11}$ Although it is possible that this process put an end to some illegal land occupation and that Maldonado de Torres rejected some dubious claims, it appears that most composiciones involving Spaniards were limited to collecting fees for the royal confirmation of existing property claims, rather than more extensive royal land redistribution.

10 Títulos de Zurite [1595] f. 1v: “declaró todas las tierras de este dho Valle ser y pertenecer a su Magestad y a su Real Corona; como en efecto le son por ser REY y Señor natural de estos Reynos: y en el les dixo y dio a entender, que su Magestad, como REY y Señor tan Poderozo, y piadozo, mandaba se les diesen y repartiesen tierras $\mathrm{p}^{\mathrm{a}}$ su sustenta, y pagar la taza, y tributo que deben, $\mathrm{y}$ para las demas cosas que hubieron menester."

11 In 1594, Pedro de Orúe's heirs petitioned the Crown for recognition of several plots near Maras, including fields the Cuzco cabildo granted to Orué in the 1550 s after confirming them as "vacant" Inca lands. Orué's heirs also presented titles for lands purchased from the royal treasurer García de Melo (who purchased them from Cuzco's cabildo in the 1550s); from a widow who inherited a herding estancia that Francisco Pizarro granted to an early conquistador; and from Inca nobles who sold their Xaquixaguana Valley lands. The record of the subsequent measurement of plots suggests that most, if not all, of these requests were granted (AGI Escribanía 506A, 1625 [1594-1595, f. $45-53])$. 
Although the composiciones de tierras in the "republic of Indians" cited the same sovereign claim of absolute authority over land, they granted lands in the royal domain to indigenous groups based on their status as tribute-paying subjects. The Toledan reforms had already adopted this stance in the 1570 s as a way of rejecting the Inca status quo ante, although Toledo's failure to overhaul indigenous land tenure ensured the continued relevance of Inca-era boundaries in rural Cuzco. By requiring royal titles for all lands, Philip II claimed the moral authority to oversee a hoped-for recovery of the Indian population, as well as the management of Spanish encroachment on indigenous landscapes. Beneath this lofty rhetoric lay the economic reality of the proceeding: royal officials designated large quantities of indigenous lands vacant and sold them to Spaniards to raise much-needed revenue, stimulating the demand for indigenous labor on private estates built from the ancestral holdings of tributary ayllus.

\section{ECOLOGICAL AND SOCIAL DIVERSITY IN FOUR REDUCCIÓN TOWNS}

Detailed land distribution records associated with the composiciones de tierras in Cuzco reducción towns expose the failure of Toledo's stated aims to reduce the power of local elites and ancestral land claims; to create new tributary towns that were egalitarian, Christian, and subject to the Crown; and to enmesh the indigenous and Spanish spheres in more symbiotic and sustainable ways. ${ }^{12}$ Our sample focuses on groups living in four reducción towns in the Xaquixaguana and Yucay Valleys to the west of Cuzco. Although the documents are not completely preserved, we transcribed and studied all available and legible parts for ayllus in Anta, Zurite, Yucay, and Maras (table 2). Our study evaluates lands allocated to 748 individuals from at least nine ayllus, including over 1928 topos and 29 papacanchas covering 2229 parcels. $^{13}$

The reducción towns congregated different repartimientos that organized themselves to meet the challenges of producing surpluses through hydraulic agriculture, cyclical dry-farmed horticulture, and mixed agropastoralism. The ayllus for which we have records represent the cosmopolitan constituency of

\footnotetext{
12 Donato Amado Gonzáles identified these documents as part of a broader regional study of archaeological sites, place names, and archival records. Records from the communities in our study, and for other groups, are often maintained by municipal officials or in private archives, and their content remains sensitive because of their legal implications.

${ }^{13}$ Composiciones measured in units based on the Castilian rod (vara), and these varied by locale. Indigenous lands were typically measured as topos, which were $93 \times 38$ varas $(\sim 0.25$ ha.) in the Xaquixaguana Valley (AGN, Derecho Indígena L.13, C.302 [1594, f. 68-73]), but $100 \times 60$ varas ( 0.42 ha.) in the Yucay Valley (Archivo de Urubamba. L.1, C.3 [1595, f. 4v]). Private property was usually measured in fanegadas (288 x 144 varas, about 2.9 ha.) (e.g., AGI Escribania 506A, 1625 [1594, f. 84v]; cf. Rostworowski 1978). Individual grants smaller than a topo were sometimes measured in papacanchas (literally, "potato enclosures"), but these do not appear to be standard units determined by colonial medidores.
} 
TABLE 2 .

Ayllus Discussed in Composición de Tierras Documents

\begin{tabular}{|c|c|c|}
\hline Town & Groups Documented & Description \\
\hline Anta & Ayllu Eqquecco & $\begin{array}{l}\text { Nearly complete account of Ayllu } \\
\text { Eqquecco repartition ( } 201 \\
\text { individuals) }\end{array}$ \\
\hline Zurite & $\begin{array}{l}\text { Ayllu Tomebamba y Curamba, Ayllu } \\
\text { Cuzco Collanas, Ayllu Circa, Ayllu } \\
\text { Suriti, Ayllu Mayo }\end{array}$ & $\begin{array}{l}\text { Individual distribution data for } \\
\text { Ayllus Suriti and Mayo; } \\
\text { description of locations and } \\
\text { boundary markers for other ayllus. }\end{array}$ \\
\hline Maras & $\begin{array}{l}\text { Ayllu Muynapampa, Ayllu Checoc y } \\
\text { Saño, Ayllu Pichingoto }\end{array}$ & $\begin{array}{l}\text { Individual repartition data from a } \\
\text { subset of ayllus in the town }\end{array}$ \\
\hline Yucay & $\begin{array}{l}\text { Ayllu Yngas Cuzco, Ayllu Guaraca, } \\
\text { Incas }\end{array}$ & $\begin{array}{l}\text { Sixty-nine individuals from an } \\
\text { unknown ayllu; also yanaconas } \\
\text { and reserved Incas }\end{array}$ \\
\hline
\end{tabular}

Sources: Anta: Títulos de Eqquecco; Zurite: Títulos de Zurite; Maras: Visita de Maras; Yucay: Archivo de Urubamba, L.1, C. 3, 1595-1865.

the Inca imperial heartland. ${ }^{14}$ Spanish officials allocated and reassigned these groups multiple times, and at the time of the composiciones many ayllus in the study area were part of the repartimientos of Beatriz Coya, the greatgranddaughter of the Inca Huayna Capac, whose Xaquixaguana and Yucay Valley holdings included more than 1300 tributaries. ${ }^{15}$ Other groups living in the same reducción towns were assigned to smaller repartimientos held by

\footnotetext{
${ }^{14}$ See Covey 2014 for a brief overview of the region in Inca times. Some reducción towns in the area had a Cuzco Ayllu comprising Inca people from the capital, and sometimes non-local retainers attached to their households. Several local communities (e.g., Anta, Eqquecco) claimed honorary ethnic Inca status in recognition of their role as lower-order imperial administrators and provincial colonists. Other pre-reducción communities appear to have been non-Inca, some of them representing resettled provincial labor colonists and retainers.

15 Although earlier viceroys had held out Huayna Capac's lands and retainers as an inducement to gain noble Inca cooperation (Covey and Elson 2007), Toledo indirectly used it to reward Martín García de Loyola for his part in capturing Tupac Amaru, the last Inca ruler in exile. Toledo offered Loyola the hand of Beatriz Coya, the heiress to what remained of Huayna Capac's estates, and the couple engaged in legal battles in the years that followed to recoup land and labor that they argued was rightfully theirs (Covey and Amado González 2008). In 1573, Toledo described Beatriz Coya's Cuzco repartimientos as comprising 2006 tributaries in the Yucay, Xaquixaguana, and Pisac valleys (1921b: 217). Documents from 1582-1583 provide Toledan tributary counts: 708 tributaries in Yucay, 366 at Caquia Xaquixaguana, and 615 at "Sanco y sus sujetos" (Cook 1975). There were also 450 tributaries at Pisac (Enríquez 1921 [1583]: 167), where nine communities serving Beatriz were reduced (Covey and Amado González 2008: 313-14 [1572, f. 444]), although she is not explicitly named in association with that grant. In 1614, Philip III granted a noble title to the estate (the Marquesado de Oropesa) to Ana María Lorenza de Loyola Coya, the daughter of Beatriz Coya and Martín García de Loyola, who had been raised at court and married Juan Enríquez de Borja.
} 
Spaniards and Inca nobles. Amidst the tributary populations were indigenous people who were exempt from tribute due to their status either as Inca nobles or retainers (yanakuna) serving colonial elites directly. ${ }^{16}$

\section{Nuestra Señora del Valle de Anta}

In 1572, Francisco de Toledo ordered the resettlement of Beatriz Coya's repartimiento. In the Xaquixaguana Valley, the existing town Anta became a new reducción called Nuestra Señora del Valle whose original population of honorary Incas was joined by the nearby communities of Cazca, Cuzco, Eqquecco, and Tambo (Covey and Amado González 2008 [1572, f. 443-44]). ${ }^{17}$ Sanco, which also served Beatriz Coya (Cook 1975), was reduced into Anta, as were the Inca towns of Conchacalla and Marco. The only group from Anta for which we have information on the composiciones is Ayllu Eqquecco.

Anta is situated near valley-bottom lands suitable for maize cultivation, but the people of Ayllu Eqquecco originally came from 4 kilometers to the northeast, in the ecotone with suni uplands (3500-3700 meters above sea level) used for cultivating tubers and European grains. In the composiciones, individuals in Ayllu Eqquecco received maize plots as well as lands for potatoes and grains and at least one fruit grove parcel. The ayllu corporately received title to various parcels for subsistence farming, including 8 topos of maize lands and 70 fanegadas for potatoes, barley, and legumes. A fanegada was designated for tasa payment and to provide for town officials.

\section{San Nicolás de Zurite}

Located on the western side of the Xaquixaguana Valley, some of the population of Zurite was in Beatriz Coya's repartimiento, along with the communities of Pomaguanca, Lavanqui, Chiguan Quiliscaches, Huarocondo, and Lacrama. These settlements were reduced into San Nicolás de Zurite in 1572, along with populations from places named Mayo, Circa, Ancahuasi, Tomebamba, and Curamba. ${ }^{18}$ Zurite was home to Inca people from Cuzco, as well as retainers (yanakuna), who were exempt from tribute (AGN, Derecho Indígena, L.7,

\footnotetext{
16 We distinguish here between Inca retainers (yanakuna) who were transplanted from their natal communities and became perpetual members of royal Inca households, and the yanaconas who lived outside of tributary communities and labored for colonial elites, who often provided them with farmland for their subsistence, and other material support. As we will discuss, such retainer relationships were popular in areas once organized as royal Inca estates, but also in new areas of intensive herding.

${ }^{17}$ In 1583 (Enríquez 1921: 167), the repartimiento of "Sanco y sus sujetos" was "reduced into three towns called Nuestra Señora del Valle [Anta], San Martín de los Quelliscaches [Huarocondo], and San Nicolás de Zurite" (rreduzidos en tres pueblos llamados nuestra señora del Valle san martin de los quelliscaches san nicolas de sorite). It is reasonable to associate the Toledan tasa with Xaquixaguana Valley communities serving Beatriz Coya.

18 Ayllu Mayo and Ayllu Circa were honorary Inca communities in Miguel Angel Felipón's encomienda (AGN, Derecho Indígena, L.3, C.38 [1595]; ARC Corregimiento, Causas Ordinarias, L.2, C.23 [1595]), who received the award for service against the English Navy (AGI Lima 209,
} 
C.95, 1637 [1606, f. 3]). ${ }^{19}$ Productive valley-bottom lands, including an extensive complex of irrigated terraces suitable for maize agriculture, at Pomaguanca, lie within the borders of the reducción town, as do areas of higher elevation grain and tuber lands (3350-3780 meters above sea level) and high pasture lands.

The surviving composición documents describe lands of several ayllus, with some general ecological classification (maize, wheat, or potato lands). Ayllu Mayu received 340 topos for subsistence farming as well as 15 topos at Peccoyguaycco for collective tribute needs. Ayllu Tumibamba had 50.5 topos for its members as well as 12 topos of wheat lands for paying the tasa. Ayllu Cuzco Collanas, which seems to have been exempt from tribute, held 520 topos of subsistence lands. The Zurite document records individual repartition of lands to this ayllu, as well as the allotments for Ayllu Zurite.

\section{San Francisco de Maras}

Maras is situated at 3200-3500 meters above sea level on a rolling plain just to the south of the Yucay Valley, an area today used for European cereals and herding because of its relatively dry conditions. The warm gullies that punctuate the plateau are favorable for maize agriculture in areas where irrigation water is available. The early colonial population of San Francisco de Maras included Inca retainers taken from several provinces, as well as local communities (Covey and Amado González 2008; Quave 2012). Although the document is incomplete, we registered individual repartition data for ninety-five individuals from three ayllus in Maras - Pichingoto, Checoc y Saño, and Muynapampa. In 1595, these ayllus were part of the repartimiento of Beatriz Coya and her husband Martín García de Loyola (Covey and Amado González 2008; Visita de Maras 1595, f. 3), whereas the remaining Maras ayllus (Maras, Mullacas) served in other repartimientos. ${ }^{20}$ The Maras repartition distinguishes between wheat and maize lands, with most individuals receiving an allotment of maize lands and twice that amount in wheat lands. Additionally, there were dispersed grants of corrals and fruit groves.

\section{Santiago de Oropesa (Yucay)}

Founded by the Inca Huayna Capac about a century before the composiciones, Yucay lies at the floor of the Urubamba Valley (2850 meters above sea level)

\footnotetext{
Número 17 [1592]). Tomebamba and Curamba appear to have had at least some members who were Inca retainers.

${ }^{19}$ By the 1580 s, some of the population ordered to settle in Zurite lived in another reducción town, San Martín de Huarocondo, with the former communities of Huarocondo, Quilescache, and Lavanqui (AGN, Títulos de Propiedad, L.18, C.359, 1647 [1588, f. 36v ff.]; cf. Julien 2012: 158). The repartimiento of Alpasondor was also reduced into Huarocondo.

${ }^{20}$ Pedro de la Gasca granted income from Maras to Pedro de Orúe (AGI Escribanía 506A 1625 $[1619$, f. $69 \mathrm{v}-70])$, who also acquired an additional encomienda through his marriage to Felipa de Guevara (AGI, Lima 199, N.37 [n.d.], f. 1v.; AGN, Superior Gobierno, L.1, C.10, 1586 [1574, f. 20-20v]; Enríquez 1921 [1583]: 166; Cook 1975: 157).
} 
surrounded by highly productive maize lands. A fragmentary copy of the 1595 repartition associated with the composiciones provides information about allotments to 179 individuals. Because many pages of the extant document are missing, it is impossible to affiliate individuals with ayllus in most cases, but records of some members of Ayllu Guaraca and Ayllu Yngas Cuzco are identifiable. Despite its incompleteness, the document offers perspectives on lands granted to Inca people and the retainers of early colonial elites. ${ }^{21}$ Populations in Yucay comprised a diverse collection of tributaries in Beatriz Coya's repartimiento, as well as tribute-exempt individuals: people of noble Inca status (Ayllu Yngas Reservados) and yanakuna settled in the valley by Inca nobles and early colonial elites. Records of individual land allotments show the prevalence of maize lands, although some members of Ayllu Guaraca also received plots classified as suitable for wheat.

\section{PATTERNS OF INDIVIDUAL LAND ALLOTMENTS}

Zurite's community land distribution commenced on 9 January 1595 with a description of the existing pattern of landholding: 1.5 topos of maize land and 2 topos of wheat land per tributary, excluding lands for the sustenance of the poor, orphans, and widows (Títulos de Zurite f. $1 \mathrm{v}-2$ ). This was accepted as the basis for the new distribution, with certain people to be given more lands than the typical allotment: "...giving preference in greater quantity for the best lands, and the closest to the town, to the caciques principales and segundas personas and ayllo curacas and other overseers, and women who had been married to caciques; and to the tributary Indians, likewise favoring with greater quantity those who have a large number of children." 22 Unmarried individuals in the town (single men, orphans, and the elderly) were to receive lands appropriate to their state. Although these instructions vary slightly for the different ayllus of Zurite, we can consider them as generally consistent with distribution priorities for other communities in our sample.

Distributions of individual allotment sizes in each reducción town (figure 2) confirm the three-tiered allocation practice described in the Zurite document, although there are local variations that deserve additional discussion. Allotments from Anta and Zurite ayllus indicate two modes that suggest default distributions for tributary households (4 topos) and unmarried

\footnotetext{
21 Although Huayna Capac's great-granddaughter Beatriz Coya inherited the repartimientos of the Yucay and Xaquixaguana valleys, there were hundreds of households in and around Yucay claiming tributary exemption as retainers of Andean (Inca and Cañari) and Spanish elites (e.g., Covey and Amado González 2008; Covey and Elson 2007). Legal disputes in the 1570s and 1580 s revolved around the reassignment of "yanaconas" to the service of the Spanish Crown instead of the repartimiento of Beatriz Coya.

22 Ibid. f. 2: “....en mas cantidad prefiriendo a los Casiques principales, y Segundas personas, y Ayllo Curacas y demas mandones, y mugeres que hayan sido de Casiques en las mejores tierras, y mas cercanas al dho Pueblo; y a los Yndios tributarios, así mismo prefiriendo en mas cantidad a los que tienen hijos en cantidad."
} 

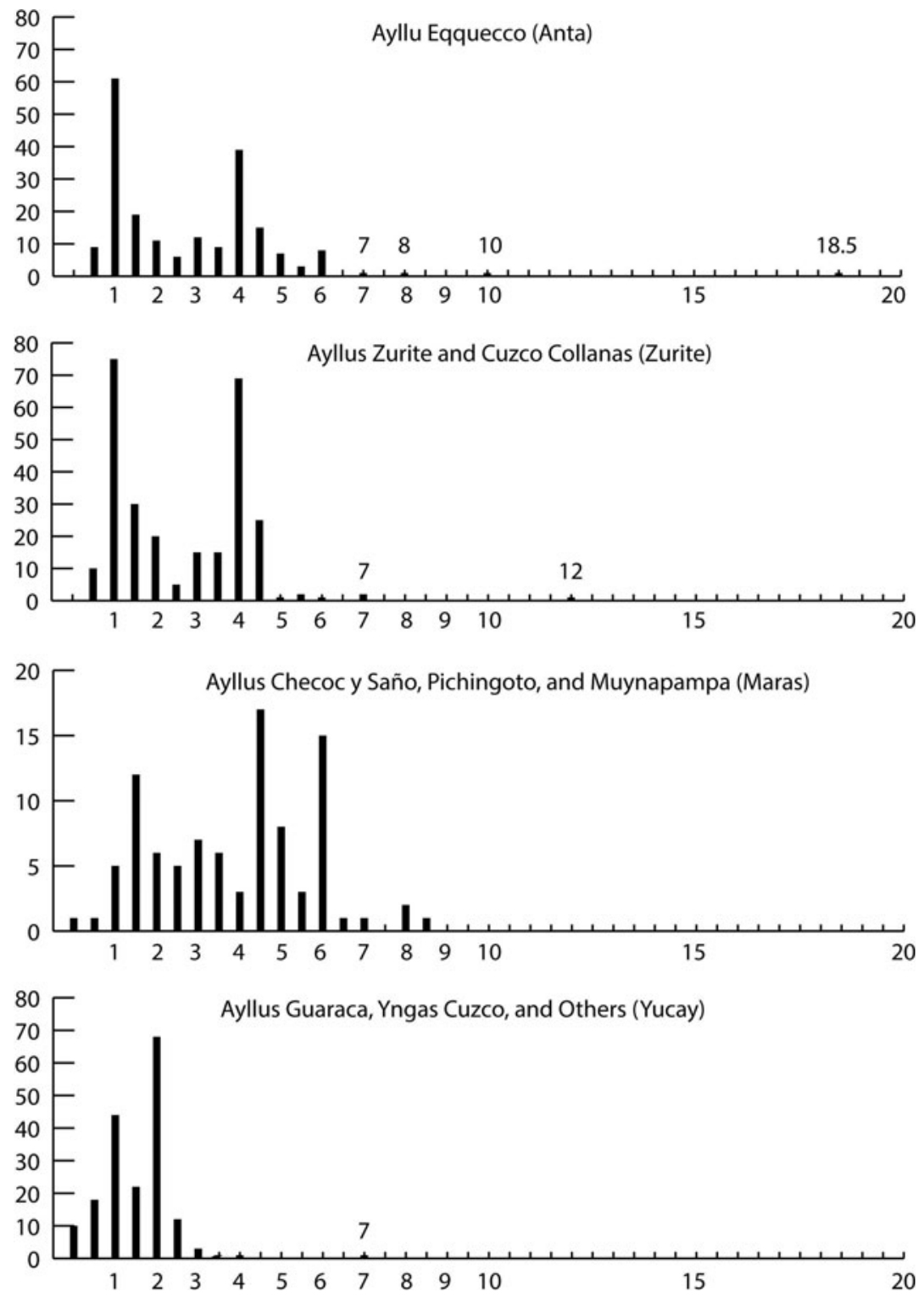

FIgURE 2. Individual land distributions in topos for the ayllus in our study. Different sized grants went to individuals, tributary households, and local elites. 
individuals (1 topo), as well as a small number of outliers that represent ayllu elites. The Maras distribution follows the same general pattern, but with slightly larger modal sizes and less-pronounced outliers. The Yucay distribution pattern is a more compressed distribution pattern with average allotments of fewer topos. ${ }^{23}$ Differences in land allocation at the level of the reducción town make it possible to discuss some of the variability in land distribution to individuals and ayllu groups.

\section{Ecology and Land Distributions to Tributary Households}

Colonial administration focused on the tributary household, represented by a married man aged eighteen to fifty. The composiciones de tierras explicitly link service to land access, and most of the land distributed in our sample of communities went to tributary households. In our study, the Maras and Yucay repartitions clearly identify tributary status, and tributary men in these towns received different amounts of land, even though they all served in the same repartimiento. In Maras, seventy-six men of tributary status received 322 topos of land, an average of 4.23 topos per household. The ninety-nine tributary men from Yucay received fewer topos than the households of Maras (1.79 topos per household; a total of 177 topos and 11 papacanchas). Even when the Yucay Valley topo is converted to the measure of the Xaquixaguana Valley, the mean size (3.04 topos) is substantially smaller than that of Maras tributaries. This difference can be attributed to ecology. In 193 places where land use for a Yucay plot was listed, all references were to maize cultivation (159 topos). By contrast, there were 413 plots in Maras with crop information; maize (214 plots, 119 topos) constituted just over half of the distributed plots, but wheat lands (199 plots, 219 topos) accounted for nearly two-thirds of the productive area handed out. Lands designated for wheat cultivation were less productive, and grants of larger plots were assigned to tributaries in areas amenable to cereal cultivation.

The distribution of Ayllu Eqquecco's transitional uplands indicates an allotment pattern that is distinct from places with large areas of maize and wheat lands. Average plot sizes were smaller in the Eqquecco distribution than in other towns, and landholders held more plots. ${ }^{24}$ Men in Eqquecco received lands in an average of seven different locations, whereas men in Yucay typically received plots in two places. The dispersed allocation of small plots in Eqquecco suggests more diverse horticultural practice across

\footnotetext{
23 Converting the Yucay Valley topos $(100 \times 60$ varas $)$ to the measure of the Xaquixaguana Valley $(93 \times 38$ varas $)$, the mean plot size (2.67 topos) is comparable to other communities.

24 Eqquecco's Hanansaya landholders had an average plot size of 0.51 topos, and the Hurinsaya average was 0.52. Averages for Maras (0.68 topos), Ayllu Zurite (0.70 topos), Yucay (0.78 topos) and Ayllu Cuzco Collanas (Zurite) (0.90 topos) were substantially larger.
} 
TABLE 3:

Percentages of Male and Female Landholders and Overall Amount of Land Granted to Women

\begin{tabular}{lrrr}
\hline \hline GROUP & Women (\%) & \multicolumn{1}{c}{ Men (\%) } & Women's Topos (\%) \\
\hline $\begin{array}{l}\text { Ayllu Zurite (Zurite) }(\mathrm{n}=101) \\
\text { Ayllu Cuzco Collanas (Zurite) }\end{array}$ & $40(39.6 \%)$ & $61(60.4 \%)$ & $51(19.9 \%)$ \\
$\quad(\mathrm{n}=170)$ & & & $76(16.7 \%)$ \\
Eqquecco Hanansaya $(\mathrm{n}=120)$ & $57(47.5 \%)$ & $63(52.5 \%)$ & $75.75(23.8 \%)$ \\
Eqquecco Hurinsaya $(\mathrm{n}=83)$ & $26(31.3 \%)$ & $57(68.7 \%)$ & $32.75(12.7 \%)$ \\
Maras (All) $(\mathrm{n}=93)$ & $14(15.1 \%)$ & $79(84.9 \%)$ & $26.5(7.1 \%)$ \\
Yucay (All) $(\mathrm{n}=181)$ & $30(16.6 \%)$ & $151(83.4 \%)$ & $19.25(6.8 \%)$ \\
\hline \hline
\end{tabular}

Note: Fragmentary and illegible items were excluded.

local microclimates, and its seasonal management would require more elaborate labor networks that might be difficult for outsiders to administer.

\section{Gender and Landholding}

The administrative rhetoric regarding tributary status as the basis for indigenous landholding promotes a gendered vision of landholding that only partially accords with the documented practices in the composiciones. Women were not counted as tributaries, but our sample records 229 women receiving land (table 3), revealing significant variability in gendered land distribution within and between communities. The proportion of female landholders was 15-17 percent among Yucay tributaries, but it represents nearly 50 percent for the Hanansaya moiety of Eqquecco Ayllu in Anta, suggesting that differences in social status and local ecology might have influenced women's access to land. On average, women received fewer plots and smaller land allotments than men in the same social group, and they did not directly control more than a quarter of the distributed land in any of our study groups.

The distribution of female-held land has a single modal size ( 1 topo) that indicates that most women did not receive lands as the heads of tributary households, but rather as individuals seen to have more modest needs than tributaries (figure 3). The documents from Zurite help to explain this pattern. Of 102 women receiving lands in Ayllu Zurite and Ayllu Cuzco Collanas, one hundred were registered as "elderly," and sixty-two of these women received a single topo of land. (There were thirty-seven elderly men in the same ayllus, and they received an average of 1.5 topos of land.) It is likely that most women receiving land in other communities were also widows who were granted small plots for their own sustenance. As with other non-tributary individuals, these women represent vulnerable labor units with limited access 


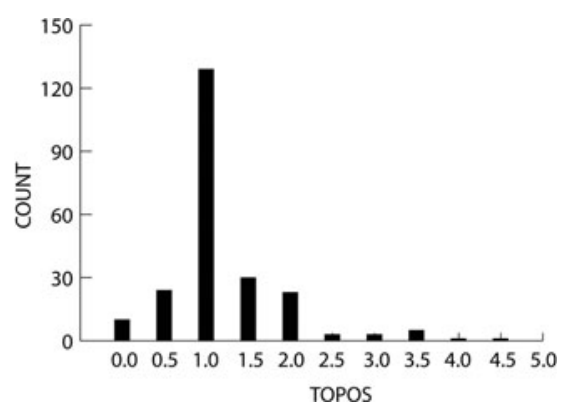

FIgURE 3. Indigenous women's landholding in our study communities indicates the allocation of small grants, primarily to widows.

to low-diversity land holdings - the one hundred older women in Zurite received a total of 167 plots of land.

There is a small number of women whose access to land does not fit this pattern. In Zurite, the two women who were granted land and not listed among the elderly were Juana Azarpay and Leonor Tacuri, both from Ayllu Zurite. Although Leonor Tacuri's identity is not known, Juana Azarpay was the wife of a local Inca lord, don García Saire Topa (Biblioteca Nacional, Ms. 20193 [c. 1626, f. 362]), one of several examples of women who received land because of elite status. In Maras, Inés Guayna Chimbo received 2 topos of wheat land, and is described as the wife of Francisco Cayo, a noble Inca. In Yucay, there were four women from the tribute-exempt Incas who received lands as wives or daughters of Inca nobles. As will be discussed below, there were other women receiving lands in the composiciones who used the title doña, as well as indigenous women who were private landowners in the areas surrounding the communities in our sample.

In addition to women of noble status, a few women in our study might have received allotments because they were married to Spaniards or were widows of tributary men who had children in their care. A woman in Maras named Beatriz Huypa received a half-topo of maize land and three corrals for herself and her children (para ella y sus hijos), although the ethnicity of her husband, Francisco García Serrano, is not obvious, and it is not certain that she was a widow. Without further documentation, it is unclear exactly why a small number of women received lands in excess of a few topos. Regardless of status, only seven women received more than 3 topos of land in the composiciones, whereas 254 men were granted at least that much land.

\section{Landholding by other Non-Tributary Individuals}

Other non-tributary individuals participated in the composiciones as landholders. Disability excused some men from tributary service, but did not necessarily 
prevent them from receiving land. Two men described as "blind" (ciego) and "crippled" (lisiado) received allotments of 0.25 and 0.5 topos, respectively. A man described as a mentally challenged (tonto) orphan received 0.75 topos of maize lands in Yucay. These grant sizes are too small to be expected to sustain an individual living alone; they might represent a modest augmentation for households caring for disabled men. Significantly, women are not represented among the disabled. Orphans represent another category of non-tributary individuals receiving lands. Eighteen orphans (fourteen male, four female) received lands in Yucay and Maras, with allotments comparable to the size granted to elderly individuals. These individuals were presumably younger than eighteen and unmarried, and thus probably affiliated with tributary households.

In addition to people unable to serve as tributaries, the composiciones document distribution of lands to a few individuals who were not subject to tributary service in the communities in our study. The documents from Maras and Yucay identify a small number of retainers (yanakuna) not described as tributaries, as well as a migrant (forastero) who married into a Yucay ayllu and was not described as a tributary. These omissions might not be significant, and other men described as retainers and migrants are also listed as tributaries. In addition to these men, two women of mixed heritage received lands - a mestiza orphan received a topo of land in Yucay, and a mulata received 2 topos in Zurite.

\section{Elite Allocations}

One goal of Toledo's reducciones was to decrease the number of indigenous elites and replace them with municipal officials serving in the newly founded colonial towns. Toledo ordered that the number of local caciques be reduced, and that they be paid determined salaries from the tasa so that they would not be able to exploit their subordinates (Mendoza y Luna 1921: 158 [16071615]). Surviving tasa documents designate a cacique for roughly every hundred tributaries, establishing a baseline for comparison with 1590s land allocations. $^{25}$ Our documents identify 405 men of tributary status across the groups in our sample, and if Toledan standards were maintained, we would expect to find a very small number of caciques. In fact, ten men are named as caciques, including five identified as cacique principal. Contemporaneous documents pertaining to nearby groups also mention a number of caciques

\footnotetext{
25 Yucay: 4 caciques for 708 tributaries (Cook 1975: 137-38); Sanco: 5 caciques for 615 tributaries (ibid., 156); Pomaguanca/Ancaguaci: 4 caciques for 348 tributaries (ibid., 156); Puquiura: 2 caciques for 231 tributaries (ibid., 157); Maras: 2 caciques for 240 tributaries (ibid., 157-58); Cupirpongo: 2 caciques for 264 tributaries (ibid. 162); Alpasondor: 1 cacique for 137 tributaries (ibid., 204).
} 
that deviates from the Toledan ordinances. ${ }^{26}$ Although the salaries of these caciques are unknown, they received more land than their neighbors - an average of more than 10 topos for each of the five caciques principales in our study communities.

In addition to men identified as repartimiento officials (caciques), lands were allocated to forty-five men and women using the honorific "don" and "doña," and these individuals generally received allotments larger than the average of their ayllus (table 4). ${ }^{27}$ In many cases, this status was linked to Inca identity. Our documents suggest that these titles were unevenly distributed within reducción towns. For example, only the cacique of Ayllu Guaraca in Yucay was called "don," whereas Ayllu Yngas Cuzco had five men of that status and the reserved Inca group had two men and six women. In Zurite, Ayllu Cuzco Collanas had more individuals of this status than Ayllu Zurite. In Ayllu Eqquecco, the upper (Hanansaya) moiety had more men with noble titles $(n=9)$ than the lower Hurinsaya moiety $(n=2)$.

The use of "don" and "doña" was common in tributary populations, as well as among the landholding neighbors of these groups. Our distribution records frequently identify the owners of plots bordering those being allocated, making it possible to identify an additional forty-three men and women called "don" and "doña." A few of these can be identified as leaders of neighboring ayllus, but there were also indigenous elites who were private landholders of fields bordering their tributary neighbors. These included descendants of the Inca royal line who held repartimientos and owned lands in the area, such as Carlos Inca and Beatriz Coya. There were also minor Inca nobles and local elites who claimed lands as ancestral grants from the Inca (e.g., AGN, Derecho Indígena, L.7, C.95 [1637]).

The composición documents from rural ayllus offer us unprecedented details of their internal organization, which in turn inform us about the social and ecological variation found among ayllus that belonged to the same repartimientos and reducciones. The procedures for conducting the land distributions and the

\footnotetext{
26 A 1590 boundary-placement proceeding names caciques principales from Ayarmaca (don Alonso Cusitaman) and Huarocondo (don Sebastián Huamantica and another man) (Títulos de Eqquecco [1590, f. 9-9v.]). Don Mateo Atauche was cacique principal of Checoc in 1592, and don Juan Usca Paucar was cacique principal of Maras in 1592 (ARC, Educandas L.2). The reducción of Cupirpongo (Chinchero) had four caciques principales - don García Poma Capa, don García de Vella, don Phelipe Caurac, and don Alonso Cusiguaman - in 1594 (Títulos de Cuper f. 51). Don Fernando Pizarro, don Martín Pizarro, and don Diego Supno were caciques principales of Ayllu Mayo in 1595 (AGN, Títulos de Propiedad, L.18, C.359 [1647], f. 32), and Don Martín Ataopoma was the segunda persona of Miguel Angel Felipón's Zurite repartimiento that year (ARC. Corregimiento Causas Ordinarias, L.2. C.23, 1595).

27 In the case of Ayllu Zurite, the two men using the "don" title were older than tributary age, and received a smaller land allotment than did most tributary households.
} 
TABLE 4.

Use of the Honorifics "Don" and "Doña" and Average Land Allotments

\begin{tabular}{|c|c|c|c|c|}
\hline AYLLU & LANDHOLDERS & $\begin{array}{l}\text { "DONS" } \\
\text { AND } \\
\text { "DOÑAS" }\end{array}$ & $\begin{array}{l}\text { AVERAGE } \\
\text { TOPOS }\end{array}$ & $\begin{array}{c}\text { AYLLU } \\
\text { AVERAGE }\end{array}$ \\
\hline $\begin{array}{l}\text { Cuzco Collanas } \\
\text { (Zurite) }\end{array}$ & 170 & 12 & 5.1 & 2.7 \\
\hline Zurite (Zurite) & 102 & 3 & 2.0 & 2.5 \\
\hline Yngas Cuzco (Yucay)* & 44 & 5 & 2.4 & 1.5 \\
\hline Guaraca (Yucay)* & 52 & 1 & 2.8 & 1.9 \\
\hline $\begin{array}{l}\text { Yngas Reservado } \\
\text { (Yucay)* }\end{array}$ & 13 & 8 & 1.3 & 1.1 \\
\hline $\begin{array}{l}\text { Unknown/Other } \\
\text { (Yucay)* }\end{array}$ & 70 & 2 & 4.6 & 1.4 \\
\hline Muynabamba (Maras)* & 29 & 4 & 6.1 & 4.9 \\
\hline Checoc y Saño (Maras) & 45 & 0 & N/A & 3.4 \\
\hline Pichingoto (Maras) & 23 & 0 & N/A & 3.5 \\
\hline Eqquecco (Anta) & 203 & 11 & 6.5 & 2.8 \\
\hline
\end{tabular}

*Incomplete documentation; averages are calculated based on recorded sample.

actual patterns of individual allotments indicate that central aims of the Toledan administrative consolidation were no longer relevant, and that royal officials continued to accept compromises while pursuing their own agendas a generation later. The documents from our study detail the expropriation of indigenous lands, the responses of ayllus whose resources were threatened, as well as the broader context of ayllu resources in the rural economy of Cuzco at the end of the sixteenth century.

\section{Disposition of "Excess" Indigenous Lands}

The process of designating boundary markers, measuring the lands belonging to a particular place, and allocating them to qualifying individuals made indigenous landscapes more legible to colonial administrators, who identified surplus lands that could be sold at auction. Indigenous distribution records represent "surpluses" as scraps of the least productive land formerly held by an ayllu, but there is evidence that large parcels of land, sometimes high-quality irrigated fields, were delimited, measured, and put up for sale. ${ }^{28}$ The continuing

${ }^{28}$ Surplus lands declared from the area of our study in 1595-1596 include 8 fanegadas of dryfarmed wheat land near Huarocondo (ARC, Corregimiento, Causas Ordinarias. L.8, C.8 [1626]), 170 topos of potato and pasture land near Pucyura (ARC, Corregimiento Causas Ordinarias, L.25, C.6 [1689-1690]), 20 fanegadas of irrigated lands at Huayoccari (near Yucay) (Archivo de Urubamba. L.1, C.7. [1595-1865]), 50 fanegadas of wheat lands near Maras (AGI Escribania 
relevance of the ayllu, and its internal elites, can be seen in short- and long-term responses to royal attempts to confiscate land.

After royal land sales, many groups received a follow-up allotment of unsold lands to augment community holdings. For example, the day after the distribution of Ayllu Eqquecco's lands, the royal commissioner increased the ayllu's community lands by granting 8 topos of maize lands and an additional 70 fanegadas of upland fields for growing maize, barley, and other crops (Tierras de Ayllu Eqquecco, f. 88v-89v). This restitution occurred after the sale of "surplus" ayllu lands, restoring a larger area than had been distributed to ayllu members a day earlier. In Zurite, the allotment of Ayllu Cuzco's lands occurred in February 1595, and was followed on 22 May by the return of 520 topos of high grassland and potato fields (Títulos de Zurite f. 43v-44).

Spanish lands were being titled and measured at the same time as many indigenous ones, and some indigenous leaders engaged actively in the proceedings pertaining to Spanish lands that bordered their own. When a Spaniard named Francisco Hernández presented titles for 13 fanegadas near the lands of Tomebamba Ayllu in Zurite, the caciques attended the measurement proceeding, protested that Hernández occupied excess lands illegally, and petitioned to receive the "surpluses" from the measurement (AGN, Derecho Indígena, L.13, C.302 [1594, f. 69v]). Successful short-term responses to local land expropriations required ayllu representatives to attend distribution proceedings, to confirm or challenge measurements and boundary placement, and to concede or fight the classification of lands as unoccupied and available for sale.

In the years following the composiciones, ayllu leaders also participated in formal legal challenges to local distributions. In principle, legal complaints were to go through Spanish officials whose salaries were paid as part of a repartimiento's tribute. This was the case in 1597, when Antonio de Neyra, the procurador de naturales (representative of natives), presented a petition on behalf of Ayllu Anta for the return of lands that were "usurped" in the composiciones (ARC, Corregimiento, Causas Ordinarias L.2, C.30 [1597]). Neyra claimed that his party had possessed the lands since ancestral times, that they used the lands to pay tribute, and that they were among the best and most fertile in the area. The natives of Anta claimed that they had been granted arid, rocky, and sterile lands in the composiciones and requested the restitution of a plot of unknown size. Although ayllu leaders must have participated in the development of the case, Neyra's petition names only the ayllu, its reducción town (Anta), and the encomienda to which it belonged.

506A, 1625 [1610, f. 4]), and 12.5 fanegadas of lands formerly belonging to Ayllu Sanco in Anta (AGN, Títulos de Propiedad, L.2, C.40 [1595, f. 2v]). 
TABLE 5 .

Lands Claimed by the Orué Family in 1594

\begin{tabular}{ll}
\hline \hline PLACE & DESCRIPTION \\
\hline Tiobamba and Chungarbamba & $\begin{array}{c}100 \text { fanegadas once belonging to Tupa Inca } \\
\text { Yupanqui }\end{array}$ \\
Caquia and Quillillibamba & $\begin{array}{c}\text { Pasture lands once belonging to Tupa Inca } \\
\text { Yupanqui }\end{array}$ \\
$\begin{array}{c}\text { Ytorobamba and Mapanache and } \\
\text { Guamantiana }\end{array}$ & $70-80$ fanegadas \\
Tiobamba and Muynabamba & 120 fanegadas of wheat lands, once belonging to \\
Guanuquia (Xaquixaguana Valley) & Lands bought from elites from Sanco \\
\hline \hline
\end{tabular}

Source: AGI Escribanía 506A [1594 f. 46].

\section{Estate Building and the Composiciones}

It is important to compare the social and ecological variations in indigenous land allocation with Spanish landholdings and labor practices in the same area. There is a stark contrast between the distribution of land to tributary ayllus and the holdings of private non-indigenous landowners. For example, the largest indigenous allotment recorded in our Maras documents was 8.5 topos to Hernando Paucar Tito, the cacique principal of Ayllu Muynabamba, an area that represents less than one fanegada. In 1594, the family of Pedro de Orué presented titles to more than 300 fanegadas of wheat and maize land in the Maras area and the Xaquixaguana Valley, as well as pastures of unknown size (table 5). When these were measured, the royal official reconfirmed 271 fanegadas. At that time, the family noted that the composiciones of indigenous groups in Maras had designated 31.5 fanegadas as vacant and surplus, parts of which the Orué family proceeded to purchase. The Orué family was not the only large landholder in the Maras area-in 1594, the Jesuits declared that they owned 100 fanegadas of wheat lands located a halfleague from Maras, and a Spaniard named Alonso Osorio claimed another 200 fanegadas (AGN, Superior Gobierno, L.2, C.35 [1617, f. 1, 3]).

Pedro de Orué received his grants of indigenous labor almost fifty years before the composiciones, and had been actively acquiring lands near Maras since the 1550 s so as to have productive resources where his tributaries could labor for him. Newer arrivals to Cuzco were also interested in building their estates by annexing vacant lands or purchasing property from Inca nobles willing to sell. For example, in 1594 the tailor Francisco Hernández declared his ownership of more than 20 topos of lands in the Xaquixaguana 
and Yucay valleys, which he had purchased from indigenous elites (AGN, Derecho Indígena, L.13, C.302 [1594]). ${ }^{29}$ During this proceeding, the tailor requested additional lands for his yanaconas to cultivate, suggesting that a Spaniard of even relatively modest means had attracted indigenous labor to his growing estate.

Indigenous elites also engaged in the protection and augmentation of personal landholdings. For example, after certain lands of Ayllu Circa (Zurite) were made available for sale, the principal of the ayllu presented an offer to purchase 2 to 3 fanegadas of unirrigated lands for barley and potato cultivation (ARC, Colegio de Educandas, Becerro 1, 1562-1724 [1595, f. 30]). A relative of this man made a second, higher bid for the land, and the two were permitted to split the purchase. This sort of economic intervention should not be viewed as a philanthropic act, although estate building by ayllu elites might have contributed to economic stability of the group over time. In nearby Calca, a cacique named don Fernando Ylla Topa Ynga found himself defending private lands, and he petitioned the viceroy in 1595 to complain that the Spaniard who conducted the visita of his personal lands had confiscated 3 fanegadas of maize lands. ${ }^{30}$ Even though he was part of a Spanish repartimiento, this Inca man claimed private ownership of lands that were almost three times as extensive as what was allotted to the Inca cacique principal in Yucay.

\section{Commodity Production and Indigenous Labor in Rural Cuzco}

The unequal distribution of land across rural Cuzco raises questions about the role of indigenous labor on private lands and the significance of wage labor for paying the tasas and building communities. By the end of the sixteenth century, Cuzco produced large quantities of livestock, wheat, maize, and coca leaf. Herding involved year-round work that was considered less rigorous than agriculture, and yanaconas frequently provided this labor on remote herding stations owned by Spaniards and Andean elites. Maize cultivation was highly productive in valley-bottom areas where Inca canals and terraces were maintained, and in well-documented areas such as the Yucay Valley, retainer labor was common in intensive farming practices (e.g., Covey and Elson 2007).

\footnotetext{
29 In the Xaquixaguana Valley at Tomebamba, Hernández bought 13 topos of maize lands from don Gonzalo Sayre Topa and doña Isabel Yuyo for 130 pesos (f. $65 \mathrm{v}-66$ ). He allegedly purchased 5 topos in the same area from doña Catalina Siuichuc, the widow of don Francisco Llaquimicta, and these were in litigation with the natives of Tomebamba (f. 66). He purchased 2 topos of valleybottom land in the Yucay Valley at Cochaguasi from don Joan Pasca Topa Inga and his wife Catalina Tapo, and a topo nearby from don Alonso Tauinpaua (f. 66-66v). He claimed another small plot in the Xaquixaguana Valley and corrals at Lluscacaca (f. 66v-67). The measurement of the composición confirmed the Xaquixaguana plots of 13 fanegadas and 5 topos, as well as a herding estancia of 3 topos bordering the lands of Tomebamba (f. $69 \mathrm{v}-73$ ).

30 ARC, Corregimiento, Causas Ordinarias L.2, C.22 [1595]. The inspector, Antonio Rodríguez, allegedly took most of the lands for himself, but he also allocated some for other Inca elites in the area, including a relative of his wife.
} 
Although some yanaconas were reduced into tributary communities, retainer labor remained important at the time of the composiciones de tierras.

By contrast, wheat cultivation took place in areas previously used for dry farming or herding, and it required large amounts of seasonal labor, particularly for harvesting and processing the crop. The alienation of indigenous lands helped to build large estates that required significant quantities of temporary labor at times that were not necessarily compatible with the labor schedules of the tributary groups ordered to provide it. In our study region, Maras offers the clearest example of the contradictions posed by Spanish demands for land and labor. Beginning in the 1550s, Spaniards conducted several proceedings to determine the availability of vacant lands around the town, and in 1586, a Spaniard living in the area testified that there were unused Inca lands in the area, as well as sufficient lands for every tributary to have 6 topos for wheat and 3 topos for maize and potatoes. ${ }^{31}$ While alleging that the indigenous population was too small to require all lands for subsistence and tribute, the large estate holders in the area also claimed that the same population could provide seasonal labor to work those lands for wheat production. For example, in 1594, the Jesuits requested ten additional workers from Maras to harvest their 100 fanegadas of wheat land, claiming that the town had thirteen unassigned workers from its séptima parte (AGN, Superior Gobierno, L.2, C.35 [1617, f. 1]). ${ }^{32}$

In Maras, demands for seasonal indigenous labor appear to have increased following the Toledan reducción and the ordinances regarding wage labor. The caciques of several groups living in Maras in 1575 cited the Toledan ordinance in a complaint over excessive service on the lands of the Augustinian order (ARC, Archivo de Colegio de Educandas L.2, 1568-1722). Fifteen years later, the heirs of Pedro de Orué sought the aid of the Cuzco corregidor to force the Indians of Maras to provide them the customary thirty workers for the harvest, which they had not sent that year (ARC, Archivo de Colegio de Educandas L.2, 1568-1722). Sancho de Orué and Pablo de Orué claimed to have 1,000 fanegadas of wheat, maize, and barley to harvest, and raised the fear of what the loss of such a crop might do to the republic. The viceroy ordered in 1590 that the Orué lands be worked by ordinary rotational laborers (mita), with nearby towns providing twenty-five workers throughout the year and eighty at the time of the harvest (AGN, Superior Gobierno, L.2, C.34 $[1613$, f. 1]). There is reason to conclude that the composiciones de tierras

\footnotetext{
31 AGN, Superior Gobierno, L.1, C.10 [1586, f. 3v-4]. Such allotments are larger than those distributed to the caciques in ayllus Pichingoto, Checoc, and Muynabamba in 1595.

32 Alonso Osorio requested workers for his 200 fanegadas in the same document, and in 1594 Bernardo Pérez del Campo requested thirty workers from Maras to harvest 169 fanegadas in the Yucay Valley (AGN, Superior Gobierno, L.2, C.16, 1594-1683, f. 23-23v). The Orué family made similar claims for wage labor in 1597 and 1598 (AGN, Superior Gobierno, L.2, C.28 $[1610$, f. $3 \mathrm{v}-6])$.
} 
accelerated the transformation of the means of production in towns like Maras -in 1602 there were more than a dozen Spaniards who claimed mita labor from Maras to maintain their lands. ${ }^{33}$

Although indigenous municipal officials participated in the administrative chain that brought estate labor demands to the ayllus living in Maras, wage labor was extracted from the ayllu, and thus from a repartimiento, which often did not correspond exactly to the reducción town or its hierarchy of municipal indigenous offices (e.g., AGN, Superior Gobierno, L.2, C.16, 1594-1683). Caciques remained important actors in the legal and informal resistance to such demands. After the composiciones de tierras eroded community lands in Maras, local caciques requested a population recount in 1597 , complaining that there were no longer enough tributaries to pay the tasa and supply private labor demands from the one-seventh levy (AGN, Superior Gobierno, L.2, C.35 [1617, f. 27]; Wightman 1990: 18-19). While pursuing relief through legal petitions, caciques sometimes chose not to cooperate with labor demands, and there are records of some being jailed for noncompliance.

A final category of indigenous labor represented in small numbers in our 1590 s communities was the migrant (forastero) who had left a tributary community to take up residence elsewhere. As noted above, three married forasteros received lands in the distribution of Ayllu Yngas Cuzco. The near absence of such migrants contrasts starkly with the indigenous population a century after the first composición. In 1689-1690, there were more forasteros than tributaries living in the jurisdictions of Anta and Zurite, and sizable migrant populations in Maras and Yucay (Villanueva Urteaga 1982). Given the apparent imbalance between the local tributary population and growing labor demands of private estates, it is not surprising to see migrant laborers attaching themselves to the nearly sixty haciendas found near the four towns in our study at the end of the seventeenth century.

\section{ONCLUSIONS}

Scholars have long recognized the inability of the Toledan administrative intensification to achieve sustained growth in both the Indian and Spanish republics in colonial Peru. By looking at communities in rural Cuzco a generation after the reducciones, this study has addressed how Toledo's master plan failed in its organization and implementation, considering how the economic transformation of the former Inca heartland contributed to disruptive realignments of the agrarian means of production. Rather than creating new communities of Christian Indians, Toledo made the cosmopolitan peoples of the Inca heartland

33 AGN, Derecho Indígena, L.4, C.44 [1602]. These include five sons of Pedro de Orué, men who married Orué's daughters (Juan de Bonilla, Pedro de Mariaca), and others who appear to be new arrivals, perhaps following the sale of indigenous lands in the preceding decade. 
into peasants whose labor was drawn into different arrangements to support the commodity production of coca, maize, wheat, and livestock. Retainers and migrants attached themselves to haciendas and estancias, whereas tributary communities were pressed for wage labor in ways that interfered with their economic self-sufficiency. The composiciones de tierras show that the processes establishing a latifundia/minifundia land distribution were well underway by the 1590s. The first sale of "surplus" indigenous lands not only expanded private landholding at the expense of community-held indigenous resources, but also set the stage for future expropriation by returning different quantities of unsold lands to ayllus. Even if indigenous populations did not continue to decline, the Crown could claim that indigenous people were known to hold far more land than was necessary for their subsistence and tributary requirements. The composiciones were repeated several times throughout the seventeenth century, helping to consolidate the processes of land tenure and labor organization that were already emerging in the 1590s.

As the colonial economic system reduced Incas to peasants, it is important to note that the ayllus in our study towns experienced different degrees of success in protecting and managing their communal lands, and in holding prominent positions in the municipal politics of the reducción towns. A century after the first composición de tierras, there were ayllus like Eqquecco that continued to represent themselves as distinct social groups, which were in a process of transitioning back to de facto autonomy on their ancestral lands. By contrast, the ayllus Checoc y Sañu, Pichingoto, and Muynapampa no longer existed in Maras, having been consolidated into a single ayllu called Loyolas (signifying their service in the Marquesado de Oropesa). There are many possibilities as to why some ayllus maintained their identity and resources, and in some cases absorbed the remnants of others. Population size, integrity of subsistence resources, and strength of internal leadership are all factors that should be considered through more intensive work with the documents in our sample. The diverse trajectories of Cuzco's indigenous populations challenge the presumptive claims regarding the implementation of Spanish colonial rule, and they also raise additional questions regarding the representation of indigenous communities in ethnohistory and ethnography.

REFERENCES

\section{Unpublished Sources}

Archivo de Urubamba, Legajo 1, Cuaderno 3 [1595]. Alonso Maldonado de Torres Visitador General de Tierras Venta y Composición, manda el reparto de las tierras del Valle de Yucay entre el Cacique, el aillo Yngas del Cuzco los viejos y viejas huérfanos y viuda.

Archivo de Urubamba, Legajo 1, Cuaderno 7 [1595]. El Licenciado Don Alonso Gutierrez de Monte Alegre saca en el publico remate 20 fanegadas de tierras de riego en el valle de Yucay y la quebrada de Guayocari a razon de 100 pesos cada fanegada. 
Archivo General de Indias (AGI), Escribanía 506A [1625]. Juan Enríquez de Borja, Marqúes de Oropesa con el fiscal y Luis de Orue y consortes ... sobre restitución de unas tierras.

Archivo General de Indias (AGI), Lima 199, Número 37 [n.d.]. Relaçion de Repartimientos del piru en cabeça de mugeres ... en cada ciudad de aquel rreyno.

Archivo General de Indias (AGI), Lima 209, Número 17 [1592]. Informaciones de oficio y parte: Miguel Angel Felipón.

Archivo General de la Nación (AGN), Derecho Indígena, Legajo 3, Cuaderno 38 [1595]. Testimonio de la repartición de tierras que Juan Salas de Valdes, por comisión del Licenciado Alonso Maldonado de Torres, hizo a los indios del valle de Jaquixaguana y del ayllo Circa, encomendados en Miguel Angel Felipón.

Archivo General de la Nación (AGN), Derecho Indígena, Legajo 4, Cuaderno 44 [1602]. Auto proveído por el Corregidor y Justicia Mayor de la provincia de Yucay, Juan Sierra de Leguizamo, en que manda a los caciques y Alcaldes del pueblo de San Francisco de Maras que formen una razón y minuta de los indios del dicho pueblo....

Archivo General de la Nación (AGN), Derecho Indígena, Legajo 7, Cuaderno 95 [1637]. Testimonio de los autos que siguió Cristobal Sanchez, con don Francisco Ramirez de Saz, Juez y Visitador de tierras en el distrito y jurisdicción de la ciudad del Cuzco, sobre composición de tierras que poseían en el valle de Saquisahuana, en términos del pueblo de San Martín de Huarocondo....

Archivo General de la Nación (AGN), Derecho Indígena, Legajo 13, Cuaderno 302 [1594]. Testimonio de la venta y composición de trece fanegadas de tierra anexas a la estancia de Tomebamba en el valle de Jaquijahuana, provincia de Abancay, que Francisco Hernandez, vecino de la ciudad del Cuzco, compuso con el Licenciado Alonso Maldonado de Torres en 1594.

Archivo General de la Nación (AGN), Superior Gobierno, Legajo 1, Cuaderno 10 [1586]. Testimonio de las diligencias que se practicaron en el pueblo de Maras, en el Cuzco, por el Licenciado Dn. Gallen de Torres, Teniente de la Corregidor de la ciudad del Cuzco, sobre la propiedad de unas tierras que fueron pastos y moyas del Inca, las cuales pretendía los Padres de la Compañía de Jesús de esa ciudad.

Archivo General de la Nación (AGN), Superior Gobierno, Legajo 2, Cuaderno 16 [1594-1683]. Autos seguidos ante el Superior Gobierno por Dn. Hernan Gonzalez de Vargas, uno de los primeros vecinos de la ciudad del Cuzco, Dn. Celedon de Ojeda y el Hermano Gregorio de Palencia, del Colegio de la Compañía de Jesús de esa ciudad, sobre que les asignen indios mitayos para el servicio de sus haciendas.

Archivo General de la Nación (AGN), Superior Gobierno, Legajo 2, Cuaderno 28 [1610]. Expediente (incompleto) que contiene los autos seguidos ante el Superior Gobierno por Dn. Tomás Alvarez Quintillana y Dña. Isabel de Orue, solicitando se le señalasen 10 indios de mita para el servicio de las tierras y ganados que poseían en el Pueblo de Maras, en el Cuzco.

Archivo General de la Nación (AGN), Superior Gobierno, Legajo 2, Cuaderno 34 [1613]. Provisión original dada por el Virrey Marqués de Cañete y ratificada por el Virrey Luis de Velazco, para que se le asigne ocho indios de provisión a Dn. Juan de Bonilla y Mejía, para el beneficio de las tierras que poseía en términos del pueblo de Maras en el Cuzco.

Archivo General de la Nación (AGN), Superior Gobierno, Legajo 2, Cuaderno 35 [1617]. Testimonio de los autos que siguió el Padre Joan Xuarez, Procurador del Colegio de la Compañía de Jesús para que se le asignasen indios de servicio para las haciendas que el Colegio tenía ... en la doctrina de Maras. 
Archivo General de la Nación (AGN), Títulos de Propiedad, Legajo 2, Cuaderno 40 [1595]. Testimonio de los autos seguidos por Juan Bautista González ... en que pide se le adjudiquen algunas tierras y solares vacos como remuneración de los servicios que tenía prestados a la Corona....

Archivo General de la Nación (AGN), Títulos de Propiedad, Legajo 18, Cuaderno 359 [1647]. Títulos de la estancia de Ipiscara o Episcara en el valle de Jaquijahuana, provincia de Abancay, jurisdicción de la ciudad del Cuzco....

Archivo Regional del Cusco (ARC), Colegio de Educandas, Legajo 2 [1568-1722].

Archivo Regional del Cusco (ARC), Colegio de Educandas, Becerro 1 [1562-1724].

Archivo Regional del Cusco (ARC), Corregimiento, Causas Ordinarias, Legajo 2, Cuaderno 22 [1595]. Autos de información de don Fernando Ylla Topa Ynga, cacique del pueblo de Calca ... sobre la restitución de unas tierras en los asientos de Vilcaura, Aycaualla, y Mollebamba.

Archivo Regional del Cusco (ARC), Corregimiento, Causas Ordinarias. Legajo 2, Cuaderno 23 [1595]. Autos sobre la confirmación de bienes hecha por don García Hurtado de Mendoza en persona de Martín Ataopoma, cacique, segunda persona del repartimiento de San Nicolás de Zurite del ayllu Mayo Hurinsaya, de la encomienda del general Miguel Angel Philipón.

Archivo Regional del Cusco (ARC), Corregimiento, Causas Ordinarias, Legajo 2, Cuaderno 30 [1597]. Petición presentada por Antonion de Nayra, procurador de los naturales en nombre de los indios del ayllu de Anta, en la encomienda de Martín García de Loyola, sobre la posesión de las tierras de Chinbaylla....

Archivo Regional del Cusco (ARC), Corregimiento, Causas Ordinarias. Legajo 8, Cuaderno 8 [1626]. Autos seguidos por Catalina Siuichimbo sobre la propiedad y posesión de unas tierras en el asiento de Condormarca en el valle de Guarocondo.

Archivo Regional del Cusco (ARC), Corregimiento, Causas Ordinarias, Legajo 25, Cuaderno 6 [1689-1690]. Autos seguidos por Juan, Alonso, Lorenzo, y Luis Guapianco y demás consortes, indios de la parroquia de Santa Ana, contra Lucas de Vidaure por el despojo de las tierras de Collana Mayo, Collanapampa, y otros nombres en el asiento de Poroy....

Biblioteca Nacional (Madrid), Ms. 20193 [ca. 1626]. Ascendencia de Melchior Carlos Inca.

Tierras de Ayllu Eqquecco, Document held in a private archive in Pucyura, Peru.

Títulos de Cuper, Archivo Notarial Ochoa, Urubamba, Peru.

Títulos de Equecco. Copy of the Libro de Repartición de Tierras de la Comunidad Eqquecco -Chakan. 1560-1730, kept by the presidente of the community.

Títulos de Zurite. Copy of a 1937 extract of the Títulos de las tierras del comun de Yndios del Pueblo de Suriti, Archivo de Ministerio de Agricultura, Sección Reconocimiento de las Comunidades.

Visita de Maras, Archivo Regional del Cusco, Archivo Histórico de la Notaria de Urubamba, Legajo 1 [1594-1595]. Repartición de tierras Valle de Urubamba Charcaguaylla-Pichingoto y San Francisco de Maras, año 1595.

\section{Published Sources}

Amado Gonzáles, Donato. 1998. Reparto de tierras indígenas y la primera visita y composición general 1591-1595. Histórica 22, 2: 197-207.

Assadourian, C. S. 1994. Transiciones hacia el Sistema Colonial Andino. Lima: Instituto de Estudios Peruanos.

Cook, Noble David, ed. 1975. Tasa de la visita general de Francisco de Toledo. Lima: Universidad Nacional Mayor de San Marcos, Dirección Universitaria de Biblioteca y Publicaciones. 
Covey, R. Alan. 2014. Local Populations, Royal Lineages, and State Entities in the Inca Occupation of the Xaquixaguana Plain. In R. A. Covey, ed., Regional Archaeology in the Inca Heartland: The Hanan Cuzco Surveys. Ann Arbor: University of Michigan Museum of Anthropology, 153-74.

Covey, R. Alan and Donato Amado González, eds. 2008. Imperial Transformations in Sixteenth-Century Yucay, Peru. Ann Arbor: University of Michigan Press.

Covey, R. Alan, Geoff Childs, and Rebecca Kippen. 2011. Dynamics of Indigenous Demographic Fluctuations: Lessons from Sixteenth-Century Cusco, Peru. Current Anthropology 52, 3: 335-60.

Covey, R. Alan and Christina M. Elson. 2007. Ethnicity, Demography, and Estate Management in Sixteenth-Century Yucay. Ethnohistory 54, 2: 303-35.

Enríquez, Martín. 1921 [1583]. Relación hecha por el Virrey D. Martín Enríquez de los oficios que se proveen en la gobernación de los reinos y provincias del Perú (1583). In Roberto Levillier, ed., Gobernantes del Perú: Cartas y papeles: Siglo XVI: Documentos del Archivo de Indias, Tomo IX. Madrid: Sucesores de Rivadeneyra, 114-230.

Gade, D. W. 1992. Landscape, System, and Identity in the Post-Conquest Andes. Annals of the Association of American Geographers 82, 3: 460-77.

Gose, Peter. 2008. Invaders as Ancestors: On the Intercultural Making and Unmaking of Spanish Colonialism in the Andes. Toronto: University of Toronto Press.

Hampe, Teodoro. 1979. Relación de los encomenderos y repartimientos del Perú en 1561. Historia y Cultura 12: 75-117.

Hanks, William F. 2010. Converting Words: Maya in the Age of the Cross. Berkeley: University of California Press.

Helmer, Marie, ed. 1955-1956. La visitación de los Indios Chupachos: Inka et encomendero, 1549. Travaux et Memoires de l'Institut Francais d'Etudes Andines 5: 3-50.

Herzog, Tamar. 2013. Colonial Law and "Native Customs": Indigenous Land Rights in Colonial Spanish America. Americas 69, 3: 303-21.

Julien, Catherine J. 2012. The Chinchaysuyu Road and the Definition of the Inca Imperial Landscape. In Susan E. Alcock, John Bodel, and Richard J. A. Talbert, eds., Highways, Byways, and Road Systems in the Pre-Modern World. Malden: Wiley, 147-67.

Levillier, Roberto. 1940. Don Francisco de Toledo, supremo organizador del Perú: Su vida, su obra (1515-1582). Buenos Aires: Espasa-Calpe.

Lovell, George and William R. Swezey. 1990. Indian Migration and Community Formation: An Analysis of Congregación in Colonial Guatemala. In David Robinson, ed., Migration in Colonial Latin America. New York: Cambridge University Press, $18-40$.

Málaga Medina, Alejandro. 1974. Las reducciones en el Perú durante el gobierno del virrey Francisco de Toledo. Anuario de Estudios Americanos 31: 819-42.

Mendoza y Luna, Juan de. 1921 [1607-1615]. Relación del estado en que se hallaba el reino del Perú. In Ricardo Beltrán y Rózpide, ed., Colección de las memorias o relaciones que escribieron los virreyes del Perú, tomo I. Madrid: Imp. Del Asilo de Huérfanos del S. C. de Jesús, 141-202.

Merluzzi, Manfredi. 2014. Gobernando los Andes: Francisco de Toledo virrey del Perú (1569-1581). Lima: Fondo Editorial PUCP.

Mumford, Jeremy. 2012. Vertical Empire: The General Resettlement of Indians in the Colonial Andes. Durham: Duke University Press.

Ondegardo, Polo de. 1917 [ca. 1564]. Copia de unos capitulos de una carta del licenciado Polo, vecino de la ciudad de la Plata para el doctor Francisco Hernández de Liebana. In Horacio H. Urteaga, ed., Informaciones acerca de la religión y gobierno de los Incas, $2^{a}$ parte. Colección de Libros y Documentos Referentes a la Historia del Perú, 4. Lima: Sanmarti, 153-204. 
Quave, Kylie E. 2012. Labor and Domestic Economy on the Royal Estate in the Inka Imperial Heartland (Maras, Cuzco, Peru). PhD diss., Department of Anthropology, Southern Methodist University, Dallas.

Robins, Nicholas A. 2011. Mercury, Mining, and Empire: The Human and Ecological Cost of Colonial Silver Mining. Bloomington: University of Indiana Press.

Rostworowski, María. 1962. Nuevos datos sobre tenencia de tierras reales en el Incario. Revista del Museo Nacional 31: 130-64.

Rostworowski, María. 1978. Mediciones y computos en el antiguo Perú. Cuadernos Prehispánicos 6: 21-40.

Rostworowski, María. 1983-1984. La tasa ordenada por el licendiado Pedro de la Gasca (1549). Revista Histórica 34: 53-102.

Saito, Akira et al. 2014. Nuevos avances en el estudio de las reducciones toledanas. Bulletin of the National Museum of Ethnology 39, 1: 123-67.

Sancho de la Hoz, Pedro. 1962 [1534]. Relación de la conquista del Perú. Madrid: Ediciones J. Porrúa Turanzas.

Scott, Heidi V. 2009. A Mirage of Colonial Consensus: Resettlement Schemes in Early Spanish Peru. Environment and Planning D: Society and Space 22: 885-99.

Stern, Steve J. 1995. The Variety and Ambiguity of Native Intervention in European Colonial Markets. In Brooke Larson and Olivia Harris, eds., Ethnicity, Markets, and Migration in the Andes: At the Crossroads of History and Anthropology. Durham: Duke University Press, 73-100.

Toledo, Francisco de. 1867a [1582]. Memorial que D. Francisco de Toledo dió al Rey nuestro Señor, del estado en que dejó las cosas del Peru, despues de haber sido en el Virey y Capitan General, trece años que comenzaron en 1569. In Relaciones de los vireyes y audiencias que han gobernado el Perú, tomo I. Lima, Imprenta del Estado, 3-32.

Toledo, Francisco de. 1867b [1572]. Ordenanzas que el señor Viso-Rey D. Francisco de Toledo hizo para el buen gobierno de estos reinos del Perú y repúblicas de el. In Relaciones de los vireyes y audiencias que han gobernado el Perú, tomo I. Lima, Imprenta del Estado, 33-154.

Toledo, Francisco de. 1867c [ca. 1574]. Ordenanzas para los indios de todos los departamentos y puelos [sic] de este reino. In Relaciones de los vireyes y audiencias que han gobernado el Perú, tomo I. Lima, Imprenta del Estado, 155-266.

Toledo, Francisco de. 1899 [1575]. Para lo que toca á la cobranza de las tercias de la ciudad del Cuzco. Revista de archivos y bibliotecas nacionales 1: 32-37.

Toledo, Francisco de. 1921a. Libro de la visita general del virrey Don Francisco de Toledo, 1570-1575. Carlos A. Romero, ed. Revista Histórica 7: 113-216.

Toledo, Francisco de. 1921b [1573]. Carta a S. M. del virrey D. Francisco de Toledo acerca de los asuntos de guerra de que de nuevo se le ofrece dar cuenta. Refiere que ha vuelto a recomendar a Abreu la población de Salta, que Cabrera no hizo, en el Tucumán (La Plata, 30 Noviembre 1573). In Roberto Levillier, ed., Gobernantes del Perú: Cartas y papeles: Siglo XVI: Documentos del Archivo de Indias. Tomo V. Madrid: Sucesores de Rivadeneyra, 190-218.

Torres Saldamando, Enrique. 1879. Reparto y composición de tierras en el Perú. Revista peruana 3: 28-34.

Varón Gabai, Rafael. 1997. Francisco Pizarro and His Brothers: The Illusion of Power in Sixteenth-Century Peru. Javier Flores Espinosa, trans. Norman: University of Oklbahoma Press.

Villanueva Urteaga, H. 1970. Documentos sobre Yucay, siglo XVI. Revista del Archivo Histórico del Cuzco 13: 1-148. 
Villanueva Urteaga, H. 1982. Cuzco 1689 documentos: economia y sociedad en el sur andino. Cusco: Centro Bartolomé de Las Casas.

Wernke, Steven A. 2013. Negotiated Settlements: Andean Communities and Landscapes under Inka and Spanish Colonialism. Tallahassee: University Press of Florida.

Wightman, A. M. 1990. Indigenous Migration and Social Change: The Forasteros of Cuzco, 1570-1720. Durham: Duke University Press.

Zuloaga Rada, Marina. 2012. La conquista negociada: guarangas, autoridades locales e imperio en Huaylas, Perú (1532-1610). Lima: Instituto de Estudios Peruanos.

\begin{abstract}
This paper uses documents generated by the 1594-1595 composiciones de tierras in Cuzco, Peru, to discuss the economic transformation of the former heartland of the Inca Empire and the impact of Spanish administrative policies implemented in the early 1570 s. The diverse social and environmental landscapes of rural areas lying to the west of Cuzco provide a range of local case studies that reveal how settlement and tribute policies of the viceroy Francisco de Toledo failed to produce sustainable colonial towns of Christian Indians. Detailed records of indigenous land repartition in the area show gender- and status-based patterns of individual allocations, as well as ecological differences in landholding between communities. The local records indicate the continuing importance of Inca-era community identities and local leadership for maintaining possession of community lands. By contrast, documents related to the composiciones among private landowners reveal vast inequalities in land access, as well as the rapid growth in the demand for indigenous labor to produce important agrarian commodities. We argue that Spanish administrative policies accelerated the transformation of the means of production in rural Cuzco, creating peasants instead of Christian Indian subjects.
\end{abstract}

Key words: land tenure, colonial Peru, Toledan reforms, composiciones de tierras, ecology, Cuzco, labor, peasants, gender, status 